\title{
Review
}

\section{Streblus asper Lour. (Shakhotaka): A Review of its Chemical, Pharmacological and Ethnomedicinal Properties}

\author{
Subha Rastogi ${ }^{1}$, Dinesh K. Kulshreshtha ${ }^{2}$ and Ajay Kumar Singh Rawat ${ }^{1}$ \\ ${ }^{1}$ Pharmacognosy and Ethnopharmacology Division, National Botanical Research Institute and \\ ${ }^{2}$ Medicinal Chemistry Division, Central Drug Research Institute, Lucknow 226001, India
}

\begin{abstract}
Streblus asper Lour is a small tree found in tropical countries, such as India, Sri Lanka, Malaysia, the Philippines and Thailand. Various parts of this plant are used in Ayurveda and other folk medicines for the treatment of different ailments such as filariasis, leprosy, toothache, diarrhea, dysentery and cancer. Research carried out using different in vitro and in vivo techniques of biological evaluation support most of these claims. This review presents the botany, chemistry, traditional uses and pharmacology of this medicinal plant.
\end{abstract}

Keywords: antifilarial - cardiac glycosides - Moraceae - Shakhotaka - Streblus asper

\section{Introduction}

Streblus asper Lour (Family: Moraceae) is a small tree (Fig. 1) which is indigenous to tropical countries such as India, Sri Lanka, Malaysia, the Philippines and Thailand. It is known by various names, e.g. Bar-inka, Berrikka, Rudi, Sheora, Koi, Siamese rough bush and Tooth brush tree (1). In India it is known by its several vernacular names, the most commonly used ones being Shakhotaka (Sanskrit), Siora (Hindi), Sheora (Bengali) and Piray (Tamil) (2). It is used traditionally in leprosy, piles, diarrhea, dysentery, elephantiasis (3) and cancer (4). It is a rigid shrub or gnarled tree; branchlets tomentose or pubescent. Leaves are 2-4 inch, rigid, elliptic, rhomboid, ovate or obovate, irregularly toothed; petiole 1/12 inch. Male heads globose, solitary or 2-nate, sometimes androgynous; peduncle short scabrid, flowers minute. Female flowers longer peduncled. Fruit pisiform; perianth yellow. It is found in the drier parts of India, from Rohilkund, eastward and southwards to Travancore, Penang and the Andaman Islands (5).

The pharmacognostical studies of its stem bark as well as its root bark have been carried out $(6,7)$. It finds place in the Ayurvedic Pharmacopoeia of India (8) and has also been

For reprints and all correspondence: Subha Rastogi, Pharmacognosy and Ethnopharmacology Division, National Botanical Research Institute,

Lucknow 226001, India. Tel: +91-0522-2205831; Fax: +91-0522-2205836;

E-mail: subharastogi1@ rediffmail.com described in some monographs (9), but none have described the complete chemistry and pharmacology of this important ethnomedicinal plant. Therefore, we aimed to compile an up-to-date and comprehensive review of $S$. asper that covers its traditional and folk medicinal uses, phytochemistry and pharmacology.

\section{Ethnomedicinal/Traditional Uses}

Streblus asper is a well known ethnomedicinal plant which is also used in Ayurveda (2,10-14). Its use in the Indian traditional folk medicine is also well documented. Table 1 gives the various traditional uses of different parts of this species and the sources of information.

\section{Phytochemistry}

Streblus asper is a rich source of cardiac glycosides. Reichstein and co-workers (15-18) have isolated more than 20 cardiac glycosides from the root bark of $S$. asper and were able to structurally characterize $\sim 15$ such compounds, mainly as a result of the application of degradative techniques, namely kamloside, asperoside, strebloside, indroside, cannodimemoside, strophalloside, strophanolloside, 16- $O$-acetylglucogitomethoside, glucogitodimethoside, glucokamloside, sarmethoside and glucostrebloside. The other glycosides

(C) The Author (2006). Published by Oxford University Press. All rights reserved.

The online version of this article has been published under an open access model. Users are entitled to use, reproduce, disseminate, or display the open access version of this article for non-commercial purposes provided that: the original authorship is properly and fully attributed; the Journal and Oxford University Press are attributed as the original place of publication with the correct citation details given; if an article is subsequently reproduced or disseminated not in its entirety but only in part or as a derivative work this must be clearly indicated. For commercial re-use, please contact journals.permissions@oxfordjournals.org 

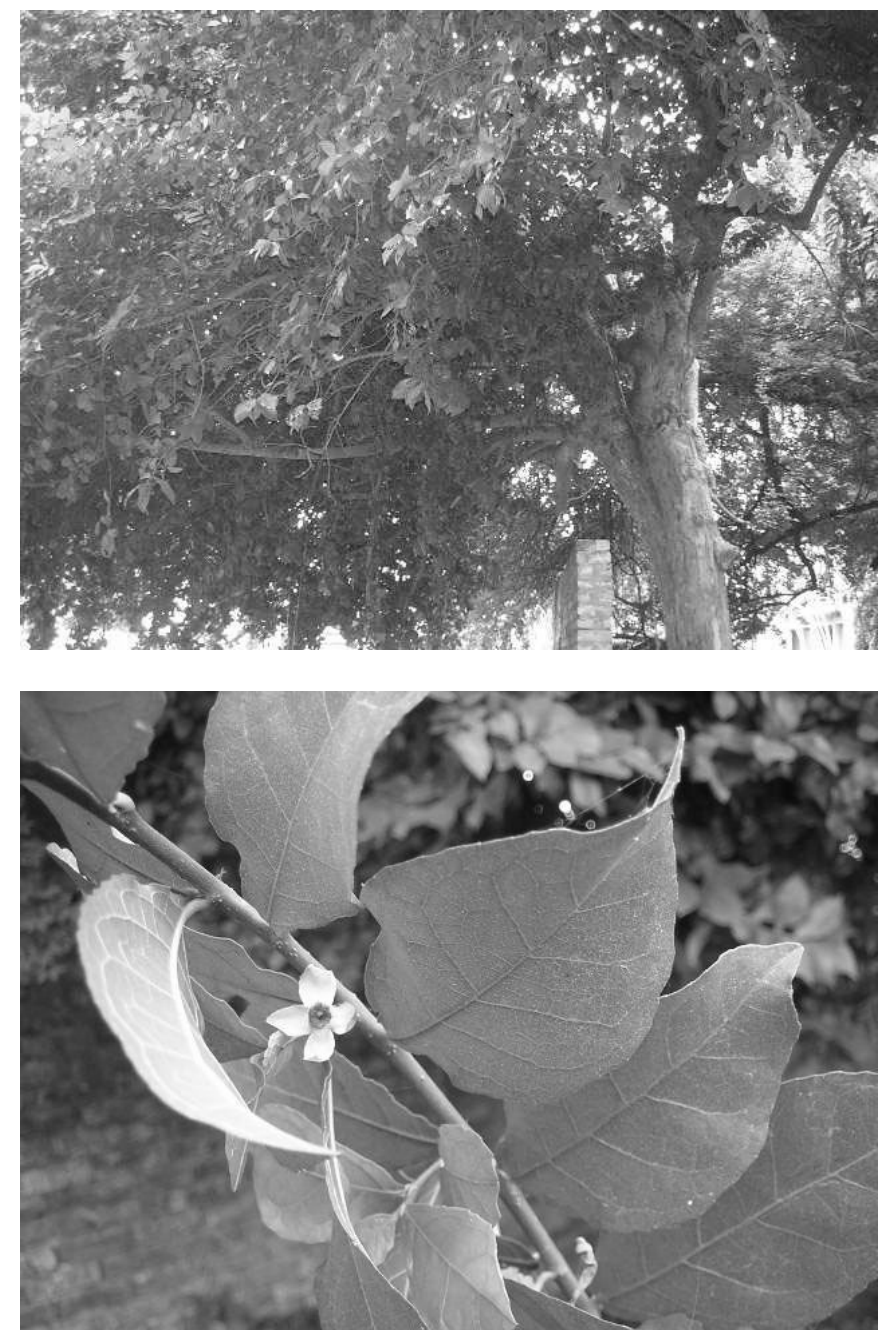

Figure 1. S. asper. (A) Whole tree. (B) Flowering twig.

Table 1. Ethnomedicinal uses of different parts of S. asper

\begin{tabular}{|c|c|c|c|}
\hline S. no. & Plant part & Traditional uses & Sources \\
\hline 1 & Root & $\begin{array}{l}\text { As an application to unhealthy ulcers } \\
\text { and sinuses and as antidote to snake } \\
\text { bite (2), in epilepsy and obesity (10) }\end{array}$ & $(2,10)$ \\
\hline 2 & Stem & Toothache (11) & (11) \\
\hline 3 & Stem bark & $\begin{array}{l}\text { Given in fever, dysentery and diar- } \\
\text { rhea }(2,10) \text {, stomachache and urinary } \\
\text { complaints }(11) \text {, useful in piles, } \\
\text { edema and wounds }(10) \text {, decoction } \\
\text { effective against lymphadema, } \\
\text { chylurea and other effects of } \\
\text { filariasis }(10,12,13)\end{array}$ & $(2,10-13)$ \\
\hline 4 & Leaves & Eye complaints (11) & (11) \\
\hline 5 & Milky juice/latex & $\begin{array}{l}\text { Antiseptic, astringent, applied to } \\
\text { chapped hands and sore feet (2), in } \\
\text { pneumonia and swells of cheek (11) }\end{array}$ & $(2,11)$ \\
\hline 6 & Fruit & Eye complaints (11) & (11) \\
\hline 7 & Seeds & Epistaxis and diarrhea (14) & (14) \\
\hline 8 & Part not specified & $\begin{array}{l}\text { Cancer, cholera, colic, diarrhea } \\
\text { dysentery and menorrhagia (4), } \\
\text { epilepsy and inflammatory } \\
\text { swellings (11) }\end{array}$ & (11) \\
\hline
\end{tabular}

reported from the roots include $\beta$-sitosterol-3-O- $\beta$-D-arabinofuranosyl- $O-\alpha$-L-rhamnopyranosyl- $O$ - $\beta$-D-glucopyranoside (19), lupanol-3- $O-\beta$-D-glucopyranosyl-[1-5]-O- $\beta$-D-xylofuranoside (20) and vijaloside, i.e. periplogenin-3-O- $\beta$-D-glucopyranosyl-[1-5]- $O-\beta-$-D-xylopyranoside (21).

From the stem bark of this plant, $\alpha$-amyrin acetate, lupeol acetate, $\beta$-sitosterol, $\alpha$-amyrin, lupeol and diol (22), strebloside and mansonin (23) have been isolated. A pregnane glycoside named sioraside (24) has also been isolated. $n$-Triacontane, tetraiacontan-3-one, $\beta$-sitosterol, stigmasterol, betulin and oleanolic acid were identified from the aerial parts (25). An unidentified cardenolide (26), $\beta$-sitosterol, $\alpha$-amyrin and lupeol were isolated from root bark and leaves (27). Figure 2 gives the structures of a few biologically active compounds that have been isolated from $S$. asper.

The volatile oil (28) from fresh leaves of $S$. asper was obtained in $0.005 \%$ yield as a brown liquid. The major constituents of the volatile oil were phytol (45.1\%), $\alpha$-farnesene (6.4\%), trans-farnesyl acetate (5.8\%), caryophyllene $(4.9 \%)$ and trans-trans- $\alpha$-farnesene (2.0\%). The other constituents were $\alpha$-copaene, $\beta$-elemene, caryophyllene, geranyl acetone, germacrene, $\delta$-cadinene, caryophyllene oxide and 8-heptadecene.

\section{Pharmacological Properties}

Several workers have reported the different biological activities of $S$. asper in various in vitro and in vivo test models. Different parts of this plant have been found to exhibit cardiotonic, antifilarial, anticancer, antimicrobial, anti-allergic and antimalarial activities. These have been described in greater detail in the following.

\section{Cardiotonic Activity}

The total ethanolic extract of the root bark of $S$. asper was found to indicate interesting activity on blood pressure, isolated frog heart, isolated rabbit intestine and guinea pig uterus. An $\alpha \beta$-unsaturated lactone was isolated which when administered by i.v. route gave the $\mathrm{LD}_{50}$ of $4.8 \mathrm{mg} \mathrm{kg}^{-1}$ in white mice. Studies on isolated frog heart showed that it induces a positive ionoptropic effect in $10^{-5}$ dilution and a systolic response in $10^{-4}$ dilution. Pronounced in vitro spasmodic effect of the compound was seen on the smooth muscles of the rabbit intestine and guinea pig uterus in those high dilutions (14). Pharmacological studies carried out have indicated that the drug has got definite action on myocardium (29).

\section{Antifilarial Activity}

The crude aqueous extract of the stem bark of S. asper revealed significant macrofilaricidal activity against Litomosoides carinii and Brugia malayi in rodents. The study revealed two cardiac glycosides, asperoside and strebloside, of the extract to be responsible for antifilarial activity. Of the two glycosides, the more effective macrofilaricide was asperoside which was active at $50 \mathrm{mg} \mathrm{kg}^{-1}$ orally against $L$. carinii in cotton rats 

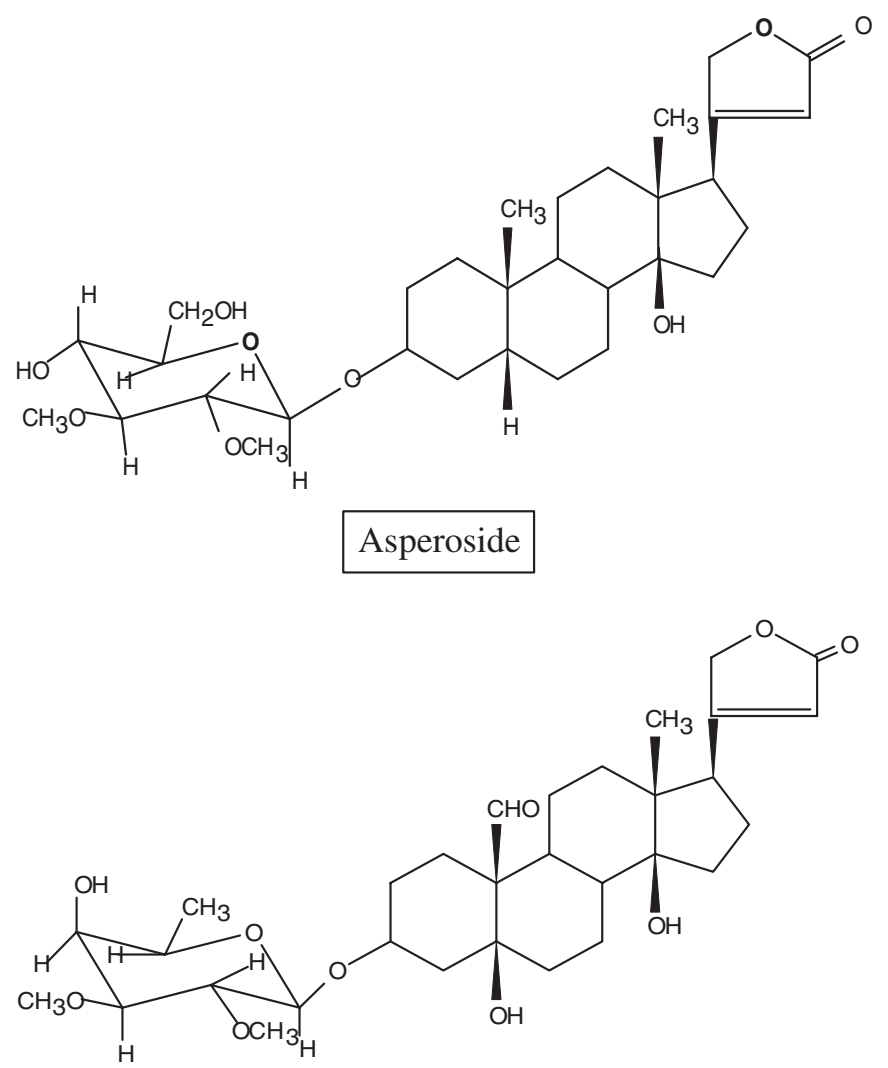

Strebloside

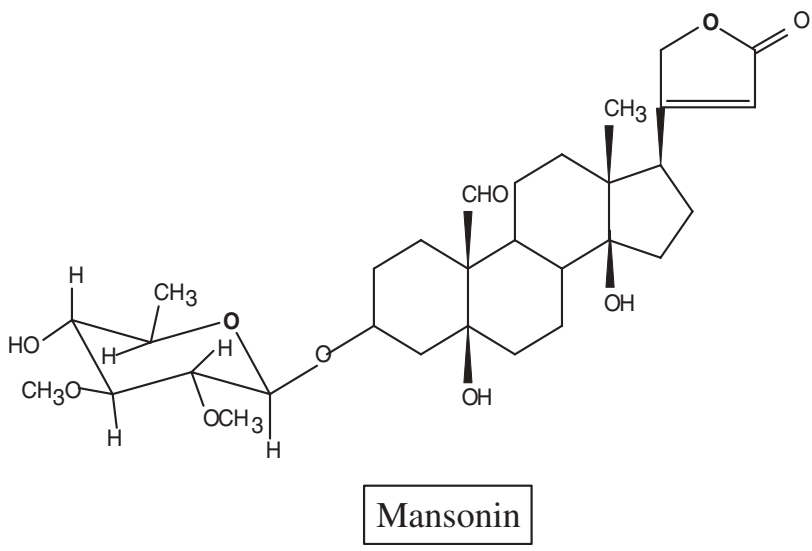

Figure 2. Structures of the biologically active compounds isolated from S. asper.

(>90\%), B. malayi in mastomys $(>70 \%)$ and Acanthocheilonema viteae in mastomys natalensis $(>70 \%)$. The glycosides were also active in vitro against all the three filarial species. Significantly weak activity was detected in glycon and aglycon portions of the parent glycosides (asperoside and strebloside). Several cardiac glycosides of other origins did not show any comparable antifilarial efficacy. The aglycosidic portion of the extract, however, showed poor adulticidal activity $(44.5 \%$ activity at $1 \mathrm{~g} \mathrm{~kg}^{-1}$ against L. carinii) (30). Streblus asper has been used in the preparation of a few formulations also.
Shakhotaka Ghana Vati prepared from its stem bark was found to be useful in filariasis (31). Besides this, another safe and effective filaricide from the stem bark of $S$. asper, 'Filacid' has also been reported. A series of extraneous investigations involving hundreds of patients infested with filarial parasites have also established its efficacy against filariasis (32).

The effect of aqueous and alcoholic extract of $S$. asper was also studied on the spontaneous movements of the whole worm and nerve-muscle preparation of Setaria cervi, the bovine filarial parasite, and on the survival of microfilariae in vitro. Aqueous as well as alcoholic extract caused inhibition of spontaneous motility of the whole worm and the nervemuscle preparation of $S$. cervi characterized by decreased tone, amplitude and rate of contractions. The concentration required to inhibit the movements of the nerve-muscle preparation was $1 / 25$ for aqueous and 1/160 for alcoholic extract suggesting a cuticular permeability barrrier. The stimulatory response of acetylcholine was blocked by alcoholic and not by aqueous extract of $S$. asper. Both alcoholic as well as aqueous extracts caused death of microfilariae in vitro, $\mathrm{LC}_{50}$ and $\mathrm{LC}_{90}$ being 90 and $33.5 \mathrm{ng} \mathrm{ml}^{-1}$, respectively (33). The in vitro effects of asperoside and strebloside on $S$. cervi females were also studied. Both asperoside and strebloside caused death of the worms within $2-3 \mathrm{~h}$ at concentrations of $10 \mathrm{~g} \mathrm{ml}^{-1}$ $(1.7 \mathrm{pmol})$ and were found to inhibit motility and glucose uptake of the parasites at lower concentrations $\left(0.1 \mathrm{~g} \mathrm{ml}^{-1}\right.$; $0.17 \mathrm{pmol})$. These glycosides also inhibited the incorporation of [U-14] C-glucose into macromolecules of S. cervi females. Parasites preincubated with either asperoside and strebloside had lowered profiles of glucokinase (EC 2.7.1.2), malate dehydrogenase (EC 1.1.1.37) and succinate dehydrogenase (EC 1.3.99.1) activities, suggesting that the lethal effects of the glycosides were owing to effects on glucose metabolism (34). It was found that asperoside and strebloside interfere with the glutathione metabolism of the adult $S$. cervi, which cause disturbance in various vital activities of the parasites that ultimately results in the death of the parasites (35).

A preliminary study of $S$. asper (shakhotak) as an antilymphoedematous agent was carried out by Baranwal et al. (36).

\section{Anticancer Activity}

Streblus asper has been reported to possess anticancer activity (37). KB cytotoxicity was found to be concentrated sequentially in the methanol and dichloromethane extracts of $S$. asper stem bark. Two cytotoxic cardiac glycosides, strebloside and mansonin, were isolated which displayed significant activity in $\mathrm{KB}$ cell culture system with $\mathrm{ED}_{50}$ values of 0.035 and $0.042 \mu \mathrm{g} \mathrm{ml}^{-1}$, respectively. An isolate is considered to be active in this system if it shows an $\mathrm{ED}_{50}$ of $\leq 4 \mu \mathrm{g} \mathrm{ml}^{-1}$ (23).

The volatile oil from fresh leaves of $\bar{S}$. asper showed significant anticancer activity $\left(\mathrm{ED}_{50} \ll 30 \mu \mathrm{g} \mathrm{ml}{ }^{-1}\right)$ from cytotoxicity primary screening tests with P388 (mouse lymphocytic leukemia) cells but no significant antioxidant activity $\left(\mathrm{IC}_{50}\right.$ values $\left.\gg 100 \mu \mathrm{g} \mathrm{ml}^{-1}\right)$ in a $\mathrm{DPPH}$ radical scavenging assay (28). 


\section{Antimicrobial Activity}

Different studies were carried out to determine the antimicrobial potential of leaves of $S$. asper (38-44). Ethanol extracts from the sticks and leaves of $S$. asper have been shown to inhibit the growth of Streptococcus mutans (38).

\section{For Oral Hygiene}

Studies demonstrated the antimicrobial activity of $S$. asper leaf extract upon various microorganisms involving oral and nasopharyngeal infections, especially $S$. mutans. Bactericidal activity was found in the $50 \%$ ethanol (v/v) extract of $S$. asper leaves. The extract possessed a selective bactericidal activity towards Streptococcus, especially to S. mutans which has been shown to be strongly associated with dental caries. The extract had no effect on cultures of Escherichia coli, Staphylococcus aureus and Pseudomonas aeruginosa, Staphylococcus coagulase positive, Staphylococcus coagulase negative, Serratia marcescens, Klebsiella pneumoniae, Enterobacter, $P$. aeruginosa, Burkholderia pseudomeallei and Candida albicans. The minimum growth inhibitory concentration and the minimum bactericidal concentration of $S$. asper extract against $10^{8} \mathrm{CFU}$ per $\mathrm{ml}$ of $S$. mutans was $2 \mathrm{mg} \mathrm{ml}^{-1}$ (39).

In vitro study was carried out to determine the effects of a sublethal concentration of $S$. asper leaf ethanolic extract on adherence of $C$. albicans to human buccal epithelial cells (HBEC). The findings indicated that the sublethal concentration of this extract may modulate candidal colonization of the oral mucosa thereby suppressing the invasive potential of the pathogen (40). An in vivo one group time series design and single blind study was carried out to determine the antimicrobial effectiveness of a mouthrinse containing $S$. asper leaf extract on $S$. mutans and total salivary bacteria following single $60 \mathrm{~s}$ rinse. The results concluded that the mouthrinse containing $S$. asper leaf extract can reduce $S$. mutans without changing an oral ecology (41). Streblus asper extract solution at $0.5 \%$ concentration (w/v) was investigated for inhibitory effect on adherence of $S$. mutans on glass surfaces. However, it did not show significant inhibitory effect on bacterial adherence to glass surfaces (42). A single blind and crossover design study was also carried out to study the effect of the mouthrinse containing $S$. asper leaf extract on gingivitis and plaque formation (43). The results revealed that when used in mouthrinse the $S$. asper leaf extract significantly effected only the gingival health. It reduced the gingival index but no significant effect was seen on plaque growth.

\section{Against Anaerobic Bacteria}

In vitro study was also carried out to determine the antibacterial effects of leaf extract of koi (S. asper) against the following six anaerobic bacteria: Porphyromonas gingivalis W50, Prevotella intermedia, Actinomyces naeslundii (T14V), Peptostreptococcus micros, Actinobacillus actinomycetemcomitans ATCC 43717 and ATCC 43718 (44). It was demonstrated that $15 \mu \mathrm{l}$ of the leaf extract at 250 and $500 \mathrm{mg} \mathrm{ml}^{-1}$ had inhibitory effects towards all bacterial strains tested except A. actinomycetemcomitans ATCC 43717. The extract had no bactericidal activity against $P$. intermedia and $A$. naeslundii (T14V). Although the extract did not show inhibitory effect towards A. actinomycetemcomitans ATCC 43717 by disc diffusion method, but it did inhibit growth of A. actinomycetemcomitans ATCC 43717 by using broth microdilution method.

\section{Anti-allergic Activity}

Streblus asper showed promising anti-allergic activity in experimental models. Anti-PCA (passive cutaneous anaphylaxis) and mast cell stabilizing activity of $S$. asper were investigated in mice and rats. Disodium cromoglycate (DSCG) was used as standard anti-allergic drug. Streblus asper (50-100 mg $\mathrm{kg}^{-1}$, p.o.) in mice showed 60-74\% anti-PCA activity. In rats it showed dose-dependent $\left(50-200 \mathrm{mg} \mathrm{kg}^{-1}\right.$, p.o.) anti-PCA activity (56-85\%). The mast cell stabilizing activity in rats (10 $\mathrm{mg} \mathrm{kg}^{-1}$, p.o. $\times 4$ days) showed $62 \%$ protection against comp. 48/80 induced degranulation. In egg albumin induced degranulation in sensitized rats there was $67 \%$ protection with $S$. asper. These results were comparable with that of $\operatorname{DSCG}\left(50 \mathrm{mg} \mathrm{kg}^{-1}\right.$, i.p.) (45).

\section{Insecticidal Activity}

Insecticidal effects have been shown in extracts of the $S$. asper stem (46). Extracts from the stem bark of S. asper possess insecticidal activity against the fifth instar of Dysdercus cingulatus. Methanolic extract showed an $\mathrm{LC}_{50}$ value of $5.56 \mu \mathrm{g}$ per insect. Partition with chloroform increased the insecticidal activity $\left(\mathrm{LC}_{50} 2.01 \mu \mathrm{g}\right.$ per insect). Three polyphenolic rich fractions were obtained from silica gel column chromatography of the chloroform fraction and found to have noteworthy insecticidal activity $\left(\mathrm{LC}_{50}: 1.82,2.70\right.$ and $2.26 \mu \mathrm{g}$ per insect) by topical application. This may provide a useful beginning for the development of biopesticides (47).

\section{Antiparasitic}

In vitro antitrypanosomal activity of aqueous extract of leaves of $S$. asper was studied at 5, 50, 500 and $1000 \mathrm{mg} \mathrm{ml}^{-1}$ (48). However, it did not show any significant activity and was thus not taken up for in vivo studies.

Das and Beuria (49) have studied the antimalarial property of the extract of $S$. asper in murine malaria. Giving the stem bark extract of $S$. asper intraperitoneally has been shown to stimulate a host immune response against Plasmodium berghei in mice.

\section{Summary and Conclusion}

Streblus asper is a well-known plant used in the Indian System of Medicine. In Ayurveda, the use of S. asper stem bark is recommended against elephantiasis for which there is no 
effective cure in the modern system of medicine. Besides this, folklore medicine also claims its use in cancer, ulcer, diarrhea, dysentery, toothache, etc. Research carried out using different in vitro and in vivo techniques of biological evaluation support most of these claims.

Filariasis, a disease of considerable public health importance, is a vector-borne helminthic infection occurring in tropical and subtropical regions of the world. Diethylcarbamazine (DEC) and ivermectin, the drugs used commonly for filariasis are insufficient because of their inadequate effect on the adult parasites. The high antifilarial activity of asperoside derived from the stem bark of $S$. asper against L. carinii, Brugia malayi and $A$. viteae in their respective hosts is unique as for the first time a cardiac glycoside has exhibited antifilarial activity. However, since the active antifilarial compounds are cardiac glycosides, they are sure to produce cardiotoxicity and thus it is necessary to dissociate the two activities. Attempts in this direction were made by the authors (50) by subjecting strebloside and asperoside to hydrogenation so as to reduce the $\alpha-\beta$ unsaturated lactone ring. The results showed that at a dose of $50 \mathrm{mg} \mathrm{kg}^{-1}$ orally, although there was a decrease in the macrofilaricidal activity exhibited by dihydroasperoside as well as dihydrostrebloside, but there was a marked absence of cardiotonic activity as compared to the parent compounds. Also the dihydro derivatives affected the reproductive ability of the female worms as they were found to be sterilized. A fraction, 'Streblofil', containing these two dihydro compounds was also prepared which also exhibited macrofilaricidal action as well as sterilized the female worms $(51,52)$. Asperoside and strebloside were also found to be effective against $S$. cervi, the bovine filarial parasite. These studies give credance to the ethnomedicinal claims of $S$. asper being an antifilarial agent.

The branch of $S$. asper has been used as a tooth brush for strengthening teeth and gums (53). Studies have also proven that it exhibits selective bactericidal activity towards Streptococcus, especially to $S$. mutans which has been shown to be strongly associated with dental caries. Streblus asper extract thus has the potential for being used as a natural product for controlling dental caries. The anticancer principles have been identified as strebloside and mansonin. Besides, the volatile oil from the fresh leaves has also shown significant anticancer activity. Studies have shown that $S$. asper possesses cardiotonic, antimalarial, anti-allergic antitrypanosomal as well as insecticidal properties. It is, therefore, in itself a very important ethnomedicinal plant whose potential is yet to be scientifically exploited.

Presently there is an increasing interest worldwide in herbal medicines accompanied by increased laboratory investigation into the pharmacological properties of the bioactive ingredients and their ability to treat various diseases (54-56). Numerous drugs have entered the international market through exploration of ethnopharmacology and traditional medicine. Although scientific studies have been done on a large number of Indian botanicals, a considerably smaller number of marketable drugs or phytochemical entities have entered the evidence-based therapeutics. Efforts are therefore needed to establish and validate evidence regarding safety and practice of Ayurvedic medicines (57).

\section{References}

1. Glasby JS. Dictionary of Plants containing Secondary Metabolites, London: Taylor and Francis, 1991, 307.

2. Chopra RN, Nayar SL, Chopra IC. Glossary of Indian Medicinal Plants, 1st edn, New Delhi: NISCOM, 1956, 235.

3. Kirtikar KR, Basu BD. Indian Medicinal Plants, Allahabad: Lalit Mohan Basu Publications: 1933;3:2291.

4. Bhakuni DS, Dhar ML, Dhar MM, Dhawan BN, Mehrotra BN. Screening of Indian plants for biological activity. Indian J Exp Biol 1969;7:250-62.

5. Hooker JD. Flora of British India, London: L. Reeve and Co., 1886;5:489.

6. Iyengar MA, Pendse GS. Studies on pharmacognosy of root bark of Streblus asper Llour. and its tincture. Indian J Pharm 1963;11:372-5.

7. Chaudhuri HN. Pharmacognostic studies on the stem bark of Streblus asper Lour. Bull Bot Surv India 1968;10:260-2.

8. The Ayurvedic Pharmacopoeia of India, Vol. III, Part I, Delhi: Department of ISM and Homoeopathy, Ministry of Health and Family Welfare, 2001;460.

9. Gupta AK, Tandon N, Sharma M. Quality Standards of Indian Medicinal Plants, Vol. II, New Delhi: Indian Council of Medical Research, 2005, 227-34.

10. Sharma PV. Dravyagun Vigyan. Chowkhambha Series, Vol. 3, 233-4.

11. Jain SK. Dictionary of Indian Folk Medicine and Ethnobotany, New Delhi: Deep Publications, 1991, 172.

12. Singh NP, Singh VK. Streblus asper Lour-an ancient Indian drug for cure of filariasis. Acta Bot Indica 1976;15:108-9.

13. Singh NP, Ram ER. Filaria and its herbal cure. New Botanist 1988;15: 201-5.

14. Useful Plants of India, New Delhi: NISCOM, 1992;603-4.

15. Khare MP, Bhatnagar SS, Schindler O, Reichstein T. Die glykoside von Streblus asper Lour. Helv Chim Acta 1962;45:1515-34.

16. Khare MP, Bhatnagar SS, Schindler O, Reichstein T. Die glykoside von Streblus asper Lour. Helv Chim Acta 1962;45:1534-46.

17. Manzetti AR, Reichstein T. Die glykoside von Streblus asper Lour. Helv Chim Acta 1964;47:2303-20.

18. Manzetti AR, Reichstein T. Die glykoside von Streblus asper Lour. Helv Chim Acta 1964;47:2320-30.

19. Chaturvedi SK, Saxena VK. $\beta$-sitosterol-3-O- $\beta$-D-arabinofuranosyl-O- $\alpha$ L-rhamnopyranosyl-O- $\beta$-D-glucopyranoside from roots of Streblus asper Lour. Acta Cienc Indica (Ser) Chem 1984;10:122-3.

20. Chaturvedi SK, Saxena VK. A new saponin lupanol-3-O- $\beta-D-$ glucopyranosyl (1-5)-O- $\beta$-D-xylofuranoside from the roots of Streblus asper. Indian J Chem 1985;24B:562.

21. Saxena VK, Chaturvedi SK. Cardiac glycosides from the roots of Streblus asper. Planta Med 1985;4:343.

22. Barua AK, Pal SK, Basu KK. Chemical examination of Streblus asper. J Indian Chem Soc 1968;45:7.

23. Fiebig M, Duh CY, Pezzuto JM, Kinghorn AD, Farnsworth NR. Plant anticancer agents, XLI. Cardiac glycosides from Streblus asper. J Nat Prod 1985;48:981-85.

24. Prakash K, Deepak D, Khare A, Khare MP. A pregnane glycoside from Streblus asper. Phytochemistry 1992;31:1056.

25. Chawla AS, Kapoor VK, Mukhopadhyay R, Singh M. Constituents of Streblus asper. Fitoterapia 1990;61:186.

26. Fernandes F, Kamat VN, Bhatnagar SS. A preliminary note on the chemical and pharmacological examination of Streblus asper Lour. Current Science 1961;30:420.

27. Mukherjee K, Roy LN. Chemical examination of Streblus asper leaves. Int J Crude Drug Res 1983;21:189-90.

28. Phutdhawong W, Donchai A, Korth J, Pyne SG, Picha P, Ngamkham J, Buddhasukh D. The components and anticancer activity of the volatile oil from Streblus asper. Flav Frag J 2004;19:445-7.

29. Gaitonde BB, Vaz AX, Patel JR. Chemical and pharmacological study of root bark of Streblus asper Linn. Indian J Med Sci 1964;18:191-9.

30. Chatterjee RK, Fatma N, Murthy PK, et al. Macrofilaricidal activity of the stembark of Streblus asper and its major active constituents. Drug Dev Res 1992;26:67-78.

31. Pandey PN, Das UK. Therapeutic assessment of Shakhotaka Ghana Vati on Slipada (Filariasis). J Res Ayur Siddha 1990;11:31-37. 
32. Hashmi S, Singh VK. Streblus asper Lour.- - an indigenous drug for the treatment of filariasis. In: Majumdar DK, Govil JN, Singh VK (eds). Recent Progress in Medicinal Plants: Ethnomedicine and Pharmacognosy, Vol. 1, Houston, Texas, USA: SCI Tech Publishing LLC, 2002, 259-19.

33. Nazneen P, Singhal KC, Khan NU, Singhal P. Potential antifilarial activity of Streblus asper against Setaria cervi (nematoda: filarioidea). Indian J Pharmacol 1989;21:16.

34. Singh SN, Chatterjee RK, Srivastava AK. Effect of glycosides of Streblus asper on motility, glucose uptake, and certain enzymes of carbohydrate metabolism of Setaria cervi. Drug Dev Res 1994;32:191-5.

35. Singh SN, Raina D, Chatterjee RK, Srivastava AK. Antifilarial glycosides of Streblus asper: effect on metabolism of adult Setaria cervi females. Helminthologia 1998;35:173-7.

36. Baranwal AK, Kumar P, Trivedi VP. A preliminary study of Streblus asper Lour. (shakhotak) as an anti-lymphoedematous agent. Nagarjun 1978;21:22-4.

37. Rastogi RP, Dhawan BN. Anticancer and antiviral activities in Indian medicinal plants: a review. Drug Dev Res 1990;19:1-12.

38. Triratana T, Thaweboon B. The testing of crude extracts of Streblus asper (Koi) against Streptococcus mutans and Streptococcus salivarius. J Dent Assoc Thai 1987;37:19-25.

39. Wongkham S, Laupattarakasaem P, Pienthaweechai K, Areejitranusorn P, Wongkham C, Techanitiswad T. Antimicrobial activity of Streblus asper leaf extract. Phytother Res 2001;15:119-21.

40. Taweechaisupapong $\mathrm{S}$, Choopan $\mathrm{T}$, Singhara $\mathrm{S}$, et al. In vitro inhibitory effect of Streblus asper leaf-extract on adhesion of Candida albicans to human buccal epithelial cells. J Ethnopharmacol 2005;96:221-6.

41. Taweechaisupapong S, Wongkham S, Chareonsuk S. Selective activity of Streblus asper on Mutans streptococci. J Ethnopharmacol 2000;70:73-9.

42. Limsong J, Benjavongkulchai E, Kuvatanasuchati J. Inhibitory effect of some herbal extracts on adherence of Streptococcus mutans. J Ethnopharmacol 2004;92:281-9.

43. Taweechaisupapong S, Wongkham S, Rattanathongkom A, Singhara S, Choopan T, Suparee S. Effect of mouthrinse containing Streblus asper leaf extract on gingivitis and plaque formation. J Dent Assoc Thai 2002;52:383-91.

44. Taweechaisupapong S, Singhara S, Choopan T. Effect of Streblus asper leaf extract on selected anaerobic bacteria. ISHS Acta Horticulturae 680: III WOCMAP Congress on Medicinal and Aromatic Plants, Vol. 6. Traditional Medicine and Nutraceuticals 2005;177-81.

45. Amarnath Gupta PP, Kulshreshtha DK, Dhawan BN. Antiallergic activity of Streblus asper. Proceedings of the XXXIV Annual conference of the
Indian Pharmacological Society. Nagpur, January 10-12, 2002, Indian J Pharmacol 2002, 211-26.

46. Atal CK. Screening of Indian medicinal plants for biological activity. Part III. Indian J Exp Biol 1969;7:250.

47. Hashim MS, Devi KS. Insecticidal action of the polyphenolic rich fractions from the stem bark of Streblus asper on Dysdercus cingulatus. Fitoterapia 2003;74:670-6.

48. Dwivedi SK. Evaluation of indigenous herbs as antitrypanosomal agents. (Vetwork UK website). http://www.vetwork.org.uk/pune13.htm.

49. Das MK, Beuria MK. Anti-malarial property of an extract of the plant Streblus asper in murine malaria. Trans R Soc Trop Med Hyg 1991;85:40-1.

50. Rastogi S. Chemical investigation of biologically active plants viz. Streblus asper, Bacopa monniera, Amoora rohituka, Bergenia stracheyi and Mallotus nepalensis. PhD Thesis 1994, Central Drug Research Institute, Lucknow (UP), India, 1994,189-96.

51. Chatterjee RK, Dhawan BN, Dwivedi AK, Fatma N, Kulshreshtha DK, Mehrotra BN, et al. A process for the preparation of dihydroasperoside and dihydrstrebloside having macrofilaricidal activity but devoid of cardiac toxicity. 2464/DEL/95.

52. Chatterjee RK, Dhawan BN, Dwivedi AK, Fatma N, Kulshreshtha DK, Mehrotra BN, et al. A process for the preparation of a standardised fraction (STREBLOFIL) from the plant Streblus asper containing dihydroasperoside and dihydrostrebloside and exhibiting macrofilaricidal properties but devoid of cardiac toxicity. 2471/DEL/95.

53. Lewis WH. Plants used as chewing sticks. J Prev Dent 1980;6:71-3.

54. Cooper EL. Complementary and alternative medicine, when rigorous, can be science. Evid Based Complement Alternat Med 2004;1:1-4.

55. Müller WEG, Batel R, Schröder HC, Müller IM. Traditional and modern biomedical prospecting: Part I-the history. Sustainable exploitation of biodiversity (sponges and invertebrates) in the Adriatic Sea at Rovinj (Croatia). Evid Based Complement Alternat Med 2004;1:71-82.

56. Mueller WEG, Schroder HC, Wiens M, Perovic-Ottstadt S, Batel R, Muller IM. Traditional and modern biomedical prospecting: Part IIthe benefits. Approaches for a sustainable exploitation of biodiversity (secondary metabolites and biomaterials from sponges). Evid Based Complement Altern Med 2004;1:133-44.

57. Patwardhan B, Warude D, Pushpangadan P, Bhatt N. Ayurveda and Traditional Chinese Medicine: A Comparative Overview. Evid Based Complement Alternat Med 2005;2:465-73.

Received December 20, 2005; accepted March 16, 2006 


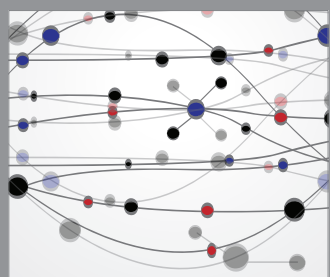

The Scientific World Journal
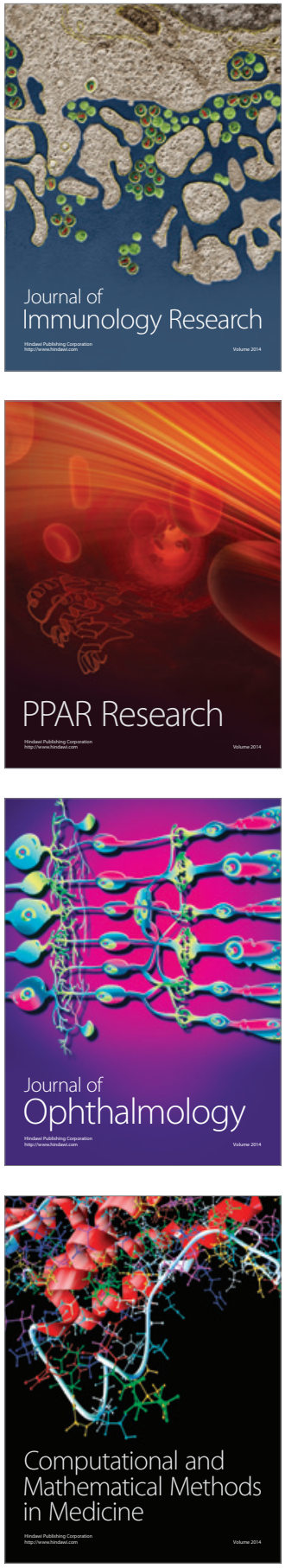

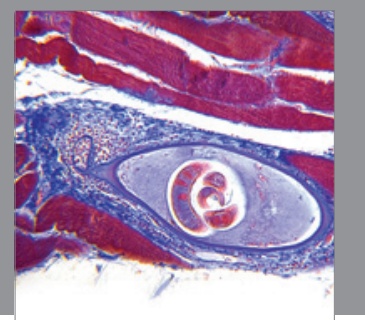

Gastroenterology

Research and Practice
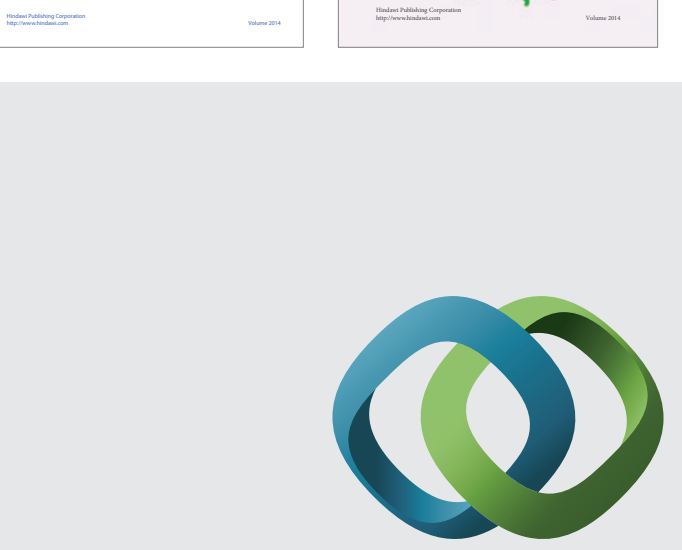

\section{Hindawi}

Submit your manuscripts at

http://www.hindawi.com
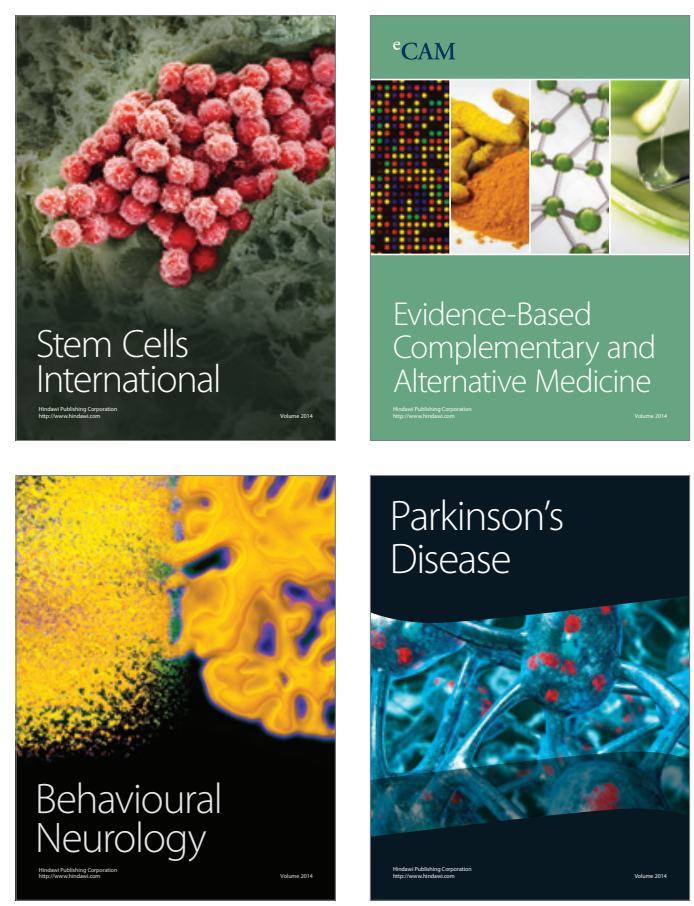

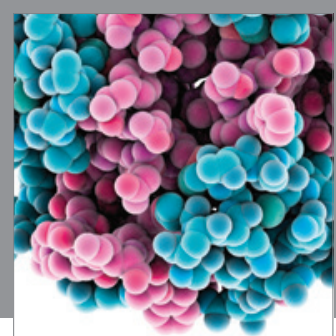

Journal of
Diabetes Research

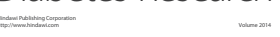

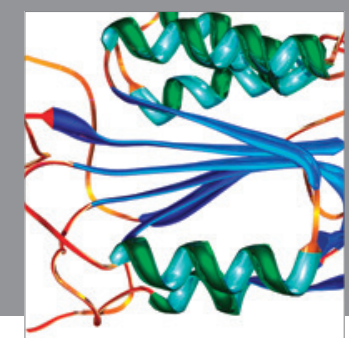

Disease Markers
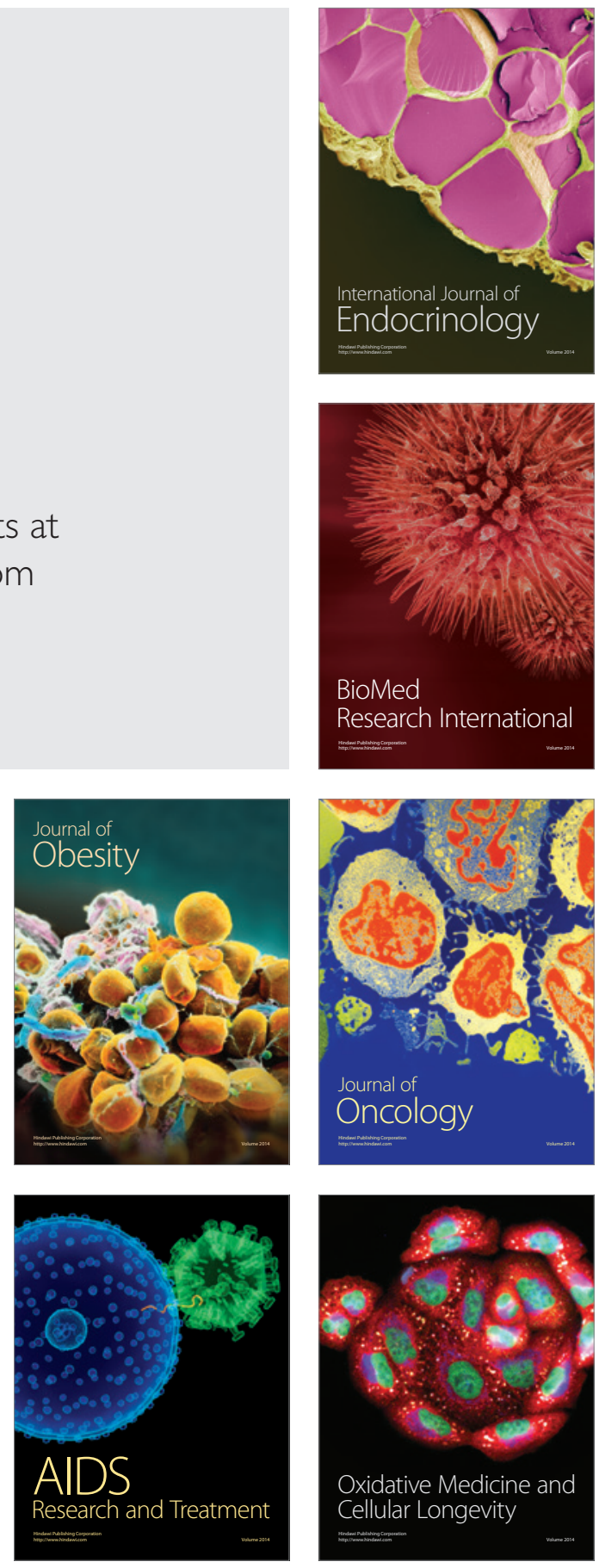